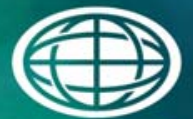

Savannah River

National Laboratory "m

OPERATED BY SAVANNAH RIVER NUCLEAR SOLUTIONS

\title{
Solvent Hold Tank Sample Results for MCU-16-1363-1364-1365: November 2016 Monthly Sample
}

\section{F. F. Fondeur \\ D. H. Jones}

March 2017

SRNL-STI-2017-00101, Revision 0 
SRNL-STI-2017-00101

Revision 0

\section{DISCLAIMER}

This work was prepared under an agreement with and funded by the U.S. Government. Neither the U.S. Government or its employees, nor any of its contractors, subcontractors or their employees, makes any express or implied:

1. warranty or assumes any legal liability for the accuracy, completeness, or for the use or results of such use of any information, product, or process disclosed; or

2. representation that such use or results of such use would not infringe privately owned rights; or

3. endorsement or recommendation of any specifically identified commercial product, process, or service.

Any views and opinions of authors expressed in this work do not necessarily state or reflect those of the United States Government, or its contractors, or subcontractors.

\section{Printed in the United States of America \\ Prepared for U.S. Department of Energy}




\title{
Solvent Hold Tank Sample Results for MCU-16-1363- 1364-1365: November 2016 Monthly Sample
}

\author{
F. F. Fondeur \\ D. H. Jones
}

March 2017

Prepared for the U.S. Department of Energy under contract number DE-AC09-08SR22470.

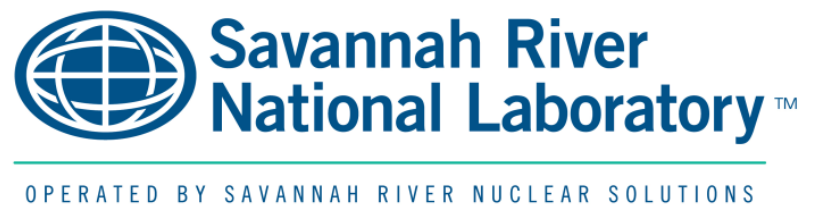




\section{REVIEWS AND APPROVALS}

\section{AUTHORS:}

F. F. Fondeur, Advanced Characterization and Processing Date

D. H. Jones, Research Support Date

TECHNICAL REVIEW:

T. B. Peters, Advanced Characterization and Processing Date Reviewed per Manual E7 Procedure 2.60

APPROVAL:

B. J. Wiedenman, Manager

Date

Advanced Characterization and Processing

D. E. Dooley, Director

Date

E\&CPT Research Programs

E. A. Brass, Manager

Date

MCU \& Salt/Sludge Processing 


\section{EXECUTIVE SUMMARY}

Savannah River National Laboratory (SRNL) received one set of three Solvent Hold Tank (SHT) samples (MCU-16-1363-1364-1365), pulled on 11/15/2016 for analysis. The samples were combined and analyzed for composition. Analysis of the composite sample MCU-16-1363-1364-1365 indicated the Isopar ${ }^{\mathrm{TM}} \mathrm{L}$ concentration is at its nominal level (100\%). The extractant (MaxCalix) and the modifier (CS$7 \mathrm{SB}$ ) are $8 \%$ and $2 \%$ below their nominal concentrations. The suppressor (TiDG) is $7 \%$ below its nominal concentration. A summary of the concentration of the relevant solvent components is shown below.

\begin{tabular}{|c|c|c|c|c|c|c|}
\hline Sample & $\begin{array}{c}\text { Sampling } \\
\text { Date }\end{array}$ & $\begin{array}{l}\text { Density } \\
\text { at } 25^{\circ} \mathrm{C} \\
(\mathrm{g} / \mathrm{mL})\end{array}$ & $\begin{array}{c}\text { IsoparTM }^{\mathrm{TM}} \mathbf{L} \\
(\mathrm{mg} / \mathrm{L})\end{array}$ & $\begin{array}{c}\text { Modifier } \\
\text { (mg/L) }\end{array}$ & $\underset{(\mathrm{mg} / \mathrm{L})}{\operatorname{MaxCalix}}$ & $\begin{array}{c}\text { TiDG } \\
(\mathrm{mg} / \mathrm{L})\end{array}$ \\
\hline MCU-16-1363-1365 & $11 / 15 / 2016$ & 0.826 & $6.09 \mathrm{E} 5$ & $1.66 \mathrm{E} 5$ & $4.23 \mathrm{E} 4$ & $1.34 \mathrm{E} 3$ \\
\hline Scratch Blend at $25^{\circ} \mathrm{C}$ & $\begin{array}{c}\text { Not } \\
\text { Applicable }\end{array}$ & 0.830 & $6.10 \mathrm{E} 5$ & $1.69 \mathrm{E} 5$ & $4.43 \mathrm{E} 4$ & $1.54 \mathrm{E} 3$ \\
\hline
\end{tabular}

This analysis confirms the trim and Isopar ${ }^{\mathrm{TM}}$ additions to the solvent in November. This analysis also indicates the solvent did not require further additions. Based on the current monthly sample, the levels of TiDG, IsoparT ${ }^{\mathrm{TM}} \mathrm{L}$, MaxCalix, and modifier are sufficient for continuing operation but are expected to decrease with time. Periodic characterization and trimming additions to the solvent are recommended.

No impurities above the $1000 \mathrm{ppm}$ level were found in this solvent by the Semi-Volatile Organic Analysis (SVOA). No impurities were observed in the Hydrogen Nuclear Magnetic Resonance (HNMR). However, there is evidence of possible chemical modification of the modifier with some missing a hydrogen atom at the tert-butyl group of the modifier. Another impurity observed in the samples was mercury. Up to $27 \pm 5.4$ micrograms of mercury per gram of solvent (or $22.3 \mu \mathrm{g} / \mathrm{mL}$ ) was detected in this sample (the average of the CV-AA and XRF methods).

The current gamma level $(1.76 \mathrm{E} 5 \mathrm{dpm} / \mathrm{mL})$ confirmed that the gamma concentration has returned to previous levels (as observed in the late 2015 samples) where the process operated normally and as expected.

The laboratory will continue to monitor the quality of the solvent in particular for any new impurities or degradation of the solvent components. 


\section{TABLE OF CONTENTS}

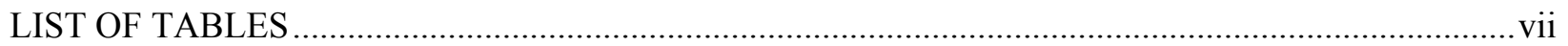

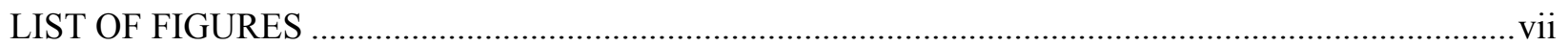

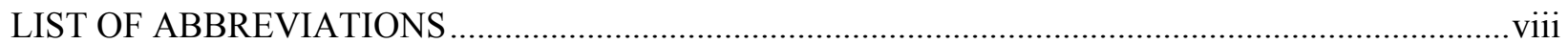

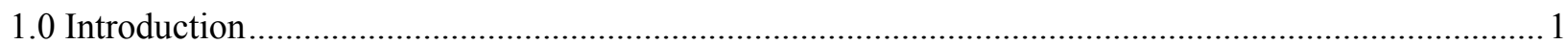

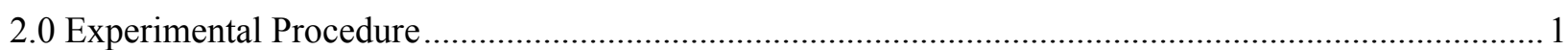

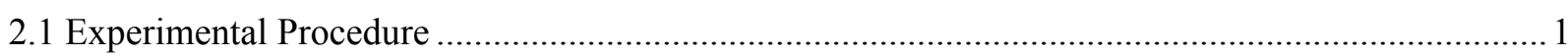

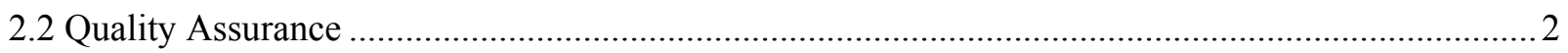

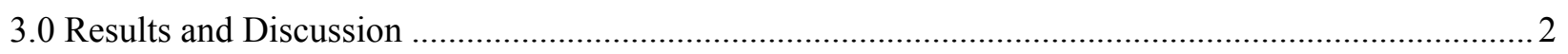

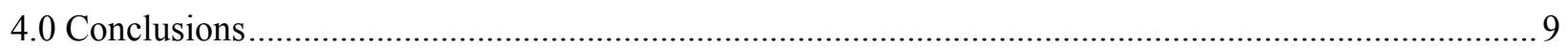

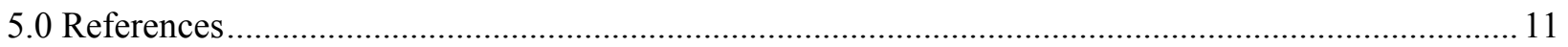




\section{LIST OF TABLES}

Table 2-1 Log of recent trims to the MCU solvent and sample arrivals to SRNL................................... 1

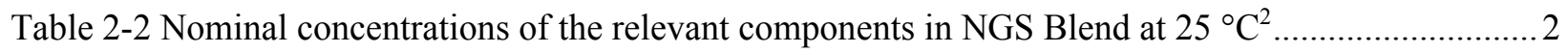

Table 3-1 Sample Results for MCU-16-1363-1364-1365 ................................................................ 4

\section{LIST OF FIGURES}

Figure 1. Typical appearance of the three MCU-16-1363, MCU-16-1364, and MCU-16-1365 ................2

Figure 2. Modifier level in the solvent as measured by HPLC (one sigma is $10 \%$ ) ................................ 5

Figure 3. Suppressor concentration as measured by titration in SHT samples since NGS implementation.

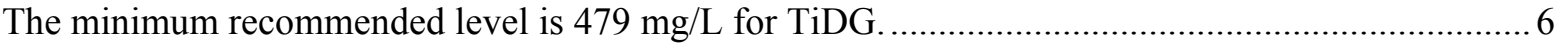

Figure 4. MaxCalix concentration as measured by HPLC and FT-HNMR of recent samples since NGS implementation $(46,000 \mathrm{mg} / \mathrm{L}$ is the nominal concentration) ..................................................... 7

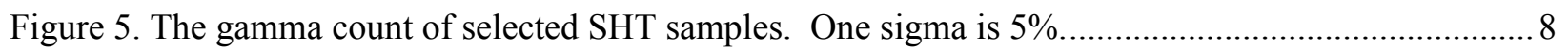

Figure 6. Total mercury in recent SHT samples. One sigma is $20 \%$. CVAA $=$ Cold Vapor Atomic Absorption Spectrometry. XRF $=$ X-ray Fluorescence $(20 \%$ one sigma). ........................................ 9 


\section{LIST OF ABBREVIATIONS}

BOBCalixC6 Calix[4]arene-bis(tert-octylbenzo-crown-6)

CSSX Caustic-Side Solvent Extraction

CVAA Cold Vapor Atomic Absorption Spectrometry

FT-HNMR Fourier Transform Hydrogen Nuclear Magnetic Resonance

FTIR Fourier transform infra-red spectroscopy

HNMR Hydrogen Nuclear Magnetic Resonance

HPLC High Performance Liquid Chromatography

ISDP Integrated Salt Disposition Project, NGS

MCU Modular Caustic-Side Solvent Extraction Unit

MaxCalix 1,3-alt-25,27-Bis(3,7-dimethyloctyloxy)calix[4]arene-benzocrown-6

NGS Next Generation Solvent

RSD Relative Standard Deviation or the absolute value of the Coefficient of Variation

SHT Solvent Hold Tank

SRNL Savannah River National Laboratory

SVOA Semi-Volatile Organic Analysis

TiDG $\quad N, N^{\prime}, N$ "-tris(3,7-dimethyloctyl)guanidine

TOA Trioctylamine

XRF X-Ray Fluorescence 


\subsection{Introduction}

In late FY13, the Modular Caustic-Side Solvent Extraction Unit (MCU) switched to the Next Generation Solvent (NGS) flow sheet. Facility personnel implemented the switch by adding a non-radioactive, NGS "cocktail" containing the new extractant (MaxCalix) and a new suppressor (TiDG) to the SHT heel. The resulting "blend" solvent ("NGS Blend solvent") is essentially NGS with residual amounts of BOBCalixC6 and trioctylamine (TOA). SHT samples are sent to SRNL to examine solvent composition changes over time.1 On November 15, 2016 Operations personnel pulled and delivered three samples from the SHT (MCU-16-1363, MCU-16-1364, and MCU-16-1365) for analysis. These samples are intended to verify that the solvent is within the specified composition range. A baseline "scratch" solvent (a scratch solvent is a preparation of all 6 solvent components at the same time to generate a solution of the appropriate composition that approximates the blend of cocktail 2 and heel solvent) was prepared in the lab (July 2016) and used for comparison and evaluation. The results from the analyses are presented in this document.

\subsection{Experimental Procedure}

\subsection{Experimental Procedure}

A summary of relevant and recent trims to the MCU solvent as well as the arrival date of the samples currently being studied are shown in Table 2-1. On November 8, 2016, a trim addition was made to MCU. 3

Table 2-1 Log of recent trims to the MCU solvent and sample arrivals to SRNL

\begin{tabular}{|c|c|}
\hline Event & Date \\
\hline SHT sample MCU-16-53-54-55 & January 25,2016 \\
\hline SHT sample MCU-16-270-271-272 & February 21,2016 \\
\hline 12 gallons of Isopar ${ }^{\mathrm{TM}} \mathrm{L}$ added to $\mathrm{MCU}$ & March 6, 2016 \\
\hline SHT sample MCU-16-348-349-350 & March 30, 2016 \\
\hline 10 gallons of Isopar ${ }^{\mathrm{TM}} \mathrm{L}$ added to $\mathrm{MCU}$ & March 31, 2016 \\
\hline April Solvent Trim added to $\mathrm{MCU}$ & April 29, 2016 \\
\hline SHT sample MCU-16-596-597-598 & April 30, 2016 \\
\hline SHT sample MCU-16-701-702-703 & May 23, 2016 \\
\hline $\begin{array}{l}\text { SHT sample MCU-16-710-711-712 (washed with } 300 \mathrm{mM} \\
\text { caustic) }\end{array}$ & May 28, 2016 \\
\hline 20 gallons solvent trim added to $\mathrm{MCU}$ & June 15,2016 \\
\hline SHT sample MCU-16-1363-1364-1365 & June 30,2016 \\
\hline SHT sample MCU-16-991-992-993 & July 23,2016 \\
\hline $\begin{array}{l}\text { SHT sample MCU-16-1033-1034-1035 (washed with } 300 \\
\text { mM caustic) }\end{array}$ & July 28, 2016 \\
\hline 20 gallons of Isopar ${ }^{\mathrm{TM}} \mathrm{L}$ added to $\mathrm{MCU}$ & August 21,2016 \\
\hline SHT sample MCU-16-1247-1248-1249 & August 22, 2016 \\
\hline SHT sample MCU-16-1317-1318-1319 & September 12,2016 \\
\hline 20 gallons solvent trim added to $\mathrm{MCU}$ & November 8, 2016 \\
\hline 11 gallon Isopar ${ }^{\mathrm{TM}} \mathrm{L}$ added to $\mathrm{MCU}$ & November 13,2016 \\
\hline SHT sample MCU-16-1363-1364-1365 & November 15,2016 \\
\hline
\end{tabular}

Samples shown in Table 2-1 were received in p-nut vials containing $\sim 10 \mathrm{~mL}$ each (see Fig 1). Once taken into a radioactive hood, the samples were visually inspected and analyzed for $\mathrm{pH}$. MCU-16-1363, MCU16-1364, and MCU-16-1365 were composited before use. Aliquots of the composited sample were removed to perform the following analysis: Density, SVOA, high performance liquid chromatography (HPLC), titration, gamma counting, CVAA, X-ray fluorescence (XRF), and Fourier-Transformed HNMR 
(FT-HNMR). Results from analytical measurements were compared with the theoretical values shown in Table 2-2.

Table 2-2 Nominal concentrations of the relevant components in NGS Blend at $25{ }^{\circ} \mathrm{C}^{2}$

\begin{tabular}{|c|c|c|}
\hline Component & $\mathbf{m g} / \mathbf{L}$ & Molar \\
\hline MaxCalix & $\sim 44,400^{\star}$ to $47,800^{*}$ & $\sim 0.0465$ to 0.050 \\
\hline BOBCalixC6* $^{*}$ & $<4,030$ & $<0.0035$ \\
\hline TOA $^{*}$ & $<530$ & $<0.0015$ \\
\hline Modifier & $\sim 169,000$ & $\sim 0.50$ \\
\hline TiDG & $\sim 1440$ & $\sim 0.003$ \\
\hline Isopar ${ }^{\text {TM }} \mathrm{L}$ & $\sim 607,000^{*}$ to $613,000^{\star}$ & $\sim 73.05$ to $73.69 \mathrm{wt} \%$ \\
\hline
\end{tabular}

*Values represent starting values when NGS blend was implemented. These components are no longer added to or refurbished in MCU. * Solvent composition is closer to a pure NGS formulation. "Solvent composition is closer to a NGS-CSSX blend formulation.

\subsection{Quality Assurance}

Requirements for performing reviews of technical reports and the extent of review are established in Manual E7 2.60. SRNL documents the extent and type of review using the SRNL Technical Report Design Checklist contained in WSRC-IM-2002-00011, Rev. 2.

\subsection{Results and Discussion}

Each sample (MCU-16-1363, MCU-16-1364, and MCU-16-1365) was visually examined. No immiscible phases or floating debris or foam were observed (see Fig. 1). All samples had a pH value of 5.5. No unusual reactions, solids, foaming, or immiscible layers were observed after combining the samples into one (MCU-16-1363-1364-1365). Table 3-1 contains the results for the MCU-16-1363-13641365 composite sample.
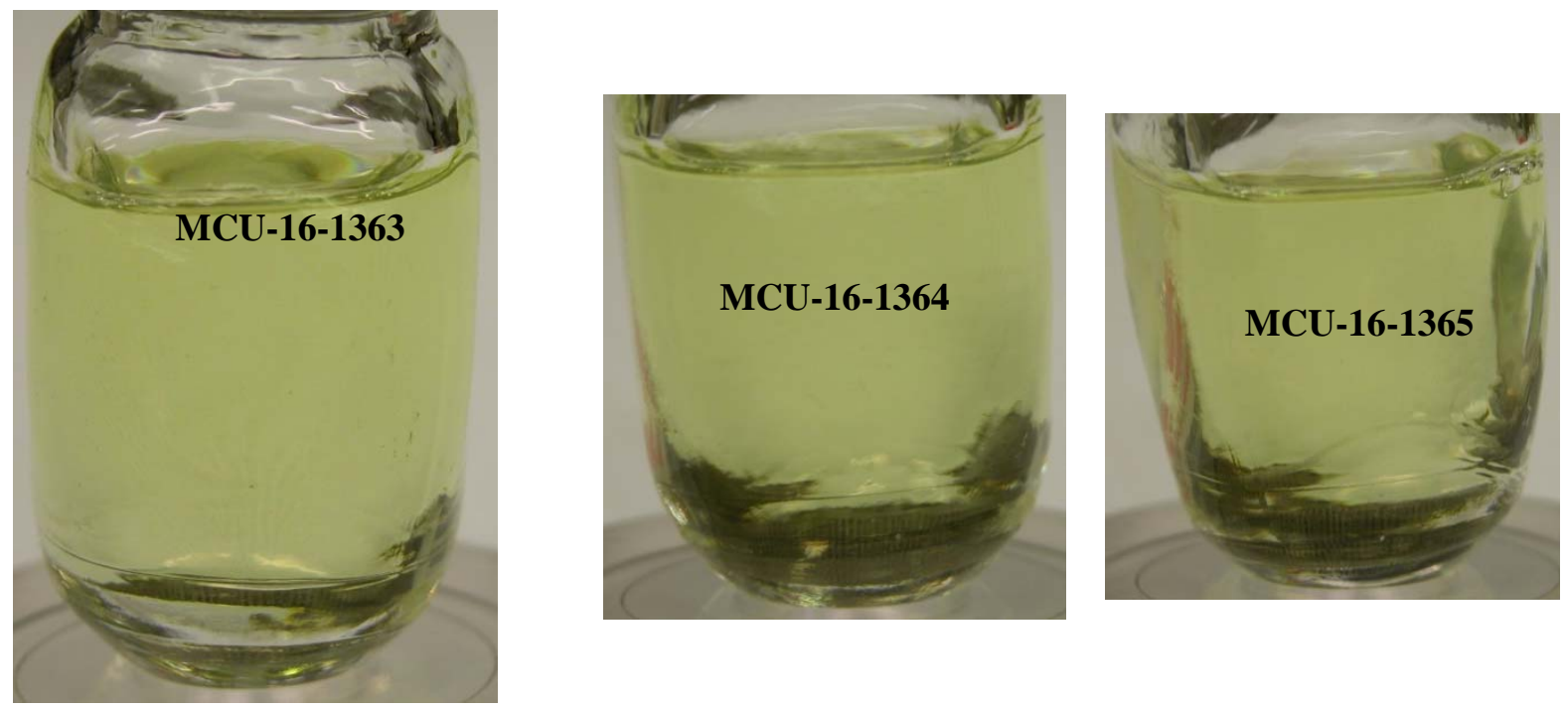

Figure 1. Typical appearance of the three MCU-16-1363, MCU-16-1364, and MCU-16-1365 


\section{Isopar $^{\mathrm{TM}} \mathrm{L}$ and Modifier Levels}

Triplicate density measurements (by gravimetric and vibrating a filled tube method) of the sample gave an arithmetic average result of $0.831 \mathrm{~g} / \mathrm{mL}(0.06 \% \mathrm{RSD})$ (or $0.826 \mathrm{~g} / \mathrm{mL}$ at $25{ }^{\circ} \mathrm{C}$ when corrected for temperature using the CSSX temperature correction formula) 4 for MCU-16-1363-1364-1365 at $18.5^{\circ} \mathrm{C}$. The calculated density $(0.826 \mathrm{~g} / \mathrm{mL})$ for MCU-16-1363-1364-1365 is about $1 \%$ below the calculated density for the standard sample $\left(0.830 \mathrm{~g} / \mathrm{mL}\right.$ at $25{ }^{\circ} \mathrm{C}$ for the scratch blend made in the laboratory). ${ }^{2,4}$ Using the density as a starting point, we know that the concentration level of the Isopar ${ }^{\mathrm{TM}} \mathrm{L}$ component in the sample should be at (or slightly above) its nominal value (within analytical uncertainties) and the modifier concentration should be slightly below its nominal value.

An examination of Table 3-1 shows that the Isopar ${ }^{\mathrm{TM}} \mathrm{L}$ concentration is at its nominal value while the modifier concentration is correspondingly slightly lower $(2 \%$ lower) than its nominal value. The Isopar ${ }^{\mathrm{TM}} \mathrm{L}$ concentration (at its nominal level) is consistent with the Isopar ${ }^{\mathrm{TM}} \mathrm{L}$ addition to the solvent on November 13. Of all the methods listed, density has the lowest uncertainty. Thus, the final reported values are closer to the density measurement. The last solvent trim addition to MCU was on November 8 , 2016.

All measurements indicate the Isopar ${ }^{\mathrm{TM}} \mathrm{L}$ level is at its nominal value while the modifier concentration level is slightly below its nominal value (see Fig. 2 for recent modifier concentrations from HPLC measurements). Looking at Fig. 2, the modifier level appears to return to its nominal level observed right after the trim addition to the solvent on November 8, 2016. The trend in the modifier level correlates with the trend in the density measurements as expected (see Fig. 2). ${ }^{4}$ The accuracies of the different measurements were within expectation as reflected in the total mass sum of the "average" results listed in Table 3-1. They added up to $0.821 \pm 0.018 \mathrm{~g} / \mathrm{mL}$. Their sum is consistent with the measured and temperature corrected (to $25{ }^{\circ} \mathrm{C}$ ) value of $0.826 \mathrm{~g} / \mathrm{mL}$, and also with the measured and corrected to $25^{\circ} \mathrm{C}$ mass concentration (density) of the standard $(0.830 \mathrm{~g} / \mathrm{mL})$. The current modifier concentration is well above the minimum modifier concentration below which the extractant concentration may drop due to solubility limits. A HNMR of the modifier revealed a possible chemical modification of approximately $5 \%$ of the modifier. Specifically, there are $5 \%$ less hydrogen in the sec-butyl group $\left(\mathrm{R}_{2} \mathrm{CH}-\mathrm{R}\right)$ of the modifier than hydrogen in the terminal $\mathrm{CF}_{2} \mathrm{H}$. The area ratio from these two groups in the H-NMR spectrum measured 0.95 when it should be one (previous last two monthly samples had area ratio of 1.01 respectively). 
Table 3-1 Sample Results for MCU-16-1363-1364-1365

\begin{tabular}{|c|c|c|c|c|c|}
\hline Analysis & Method & $\begin{array}{l}\text { LW-AD-Proj- } \\
\text { 160412-4 } \\
\text { (Analytical } \\
\text { Lab. Labeling) }\end{array}$ & $\begin{array}{l}\text { Result } \\
(\mathbf{m g} / \mathbf{L})^{\#}\end{array}$ & $\begin{array}{c}\text { Nominal* Result } \\
\text { (mg/L) }\end{array}$ & $\begin{array}{c}\% \text { of (Result } \div \\
\text { Nominal Result) }\end{array}$ \\
\hline Isopar ${ }^{\mathrm{TM}} \mathrm{L}$ & FT-HNMR & NA & $6.14 \mathrm{E}+05$ & \multirow{3}{*}{$6.10 \mathrm{E}+05$} & 101 \\
\hline IsoparTML & FTIR & $\mathrm{NA}$ & $6.22 \mathrm{E}+05$ & & 102 \\
\hline IsoparTML & Density & $\mathrm{NA}$ & $6.08 \mathrm{E}+05$ & & 100 \\
\hline Average $^{\$}$ & All & NA & $6.09 \mathrm{E}+05$ & $6.10 \mathrm{E}+05$ & 100 \\
\hline Modifier & HPLC & LW4682 & $1.67 \mathrm{E}+05$ & \multirow{4}{*}{$1.69 \mathrm{E}+05$} & 99 \\
\hline Modifier & FT-HNMR & NA & $1.58 \mathrm{E}+05$ & & 94 \\
\hline Modifier & FTIR & NA & $1.58 \mathrm{E}+05$ & & 94 \\
\hline Modifier & Density & $\mathrm{NA}$ & $1.67 \mathrm{E}+05$ & & 99 \\
\hline Average $^{\$}$ & All & $\mathrm{NA}$ & $1.66 \mathrm{E}+05$ & $1.69 \mathrm{E}+05$ & 98 \\
\hline TiDG & Titration-SVOA* & LW4681 & $1.20 \mathrm{E}+03$ & $1.44 \mathrm{E}+03$ & 83 \\
\hline $\mathrm{TiDG}^{\star}$ & Titration & NA & $1.38 \mathrm{E}+03$ & $1.44 \mathrm{E}+03$ & 96 \\
\hline Average $^{\$}$ & All & NA & $1.34 \mathrm{E}+03$ & $1.44 \mathrm{E}+03$ & 93 \\
\hline trioctylamine & SVOA & LW4681 & $3.10 \mathrm{E}+02$ & - & $58 x$ \\
\hline trioctylamine & Titration & $\mathrm{NA}$ & $1.72 \mathrm{E}+02$ & - & $32 x$ \\
\hline Average $^{\$}$ & All & NA & $1.94 \mathrm{E}+02$ & - & $37 x$ \\
\hline MaxCalix & HPLC & LW4682 & $4.20 \mathrm{E}+04$ & \multirow{2}{*}{$4.60 \mathrm{E}+04^{\Delta}$} & 91 \\
\hline MaxCalix & FT-HNMR & NA & $4.29 \mathrm{E}+04$ & & 93 \\
\hline Average $^{\$}$ & All & NA & $4.23 \mathrm{E}+04$ & $4.60 \mathrm{E}+04^{\Delta}$ & 92 \\
\hline BOBCalixC6 & HPLC & LW4682 & $1.79 \mathrm{E}+03$ & - & $44 x$ \\
\hline Average $^{\$}$ & All & NA & $1.79 \mathrm{E}+03$ & - & $44^{x}$ \\
\hline $\begin{array}{l}\text { Density } \\
(\mathrm{g} / \mathrm{mL})\end{array}$ & Direct Measurement & NA & 0.826 & 0.83 & 99 \\
\hline
\end{tabular}

\# Analytical uncertainty is $10 \%$ for HPLC. Titration method uncertainty is $10 \%$ for TiDG and $16 \%$ for TOA. Density results from the average of replicate volumetric trials typically have a percentage standard deviation of $<3 \%$ between each value and the average. NMR analytical uncertainty is $10 \%$ for the modifier and $13 \%$ for MaxCalix, and $14 \%$ for Isopar ${ }^{\mathrm{TM}} \mathrm{L}$. N/A $=$ Not Applicable. Density estimations assume the combined weight percent of TiDG, MaxCalix, BOBCalixC6, and TOA to be approximately 6\%. All uncertainties are 1 sigma.

${ }^{*}$ Nominal value is the expected value for freshly prepared blended solvent with a target density of $0.8352 \mathrm{~g} / \mathrm{mL}$ at $25^{\circ} \mathrm{C}$.

${ }^{\$}$ Reported value for a MCU component is the weighted average of the values reported by the techniques that measured that component. $x=\frac{\sum_{1}^{i}\left(x_{i} / \delta_{i}^{2}\right)}{\sum_{1}^{i}\left(1 / \delta_{i}^{2}\right)} ; \quad \begin{aligned} & x_{i} \text { stands for the concentration obtained at a given method and } \delta_{i} \text { is the } \\ & \text { corresponding uncertainty. }\end{aligned}$

- No TiDG value was estimated by FT-HNMR due to an aged (questionable) standard.

* Trioctylamine obtained from the SVOA method was subtracted from the measured total base in the titration method to obtain a calculated TiDG concentration.

${ }^{\chi}$ Percentages are relative to the initial TOA concentration of $530 \mathrm{mg} / \mathrm{L}$ and BOBCalixC6 concentration of $4030 \mathrm{mg} / \mathrm{L}$ in 2008 .

${ }^{\Delta}$ Value shown is the difference between $47,800 \mathrm{mg} / \mathrm{L}$ ( $50 \mathrm{mM}$ MaxCalix) and the current BOBCalixC6 concentration $(1,790 \mathrm{mg} / \mathrm{L})$. 


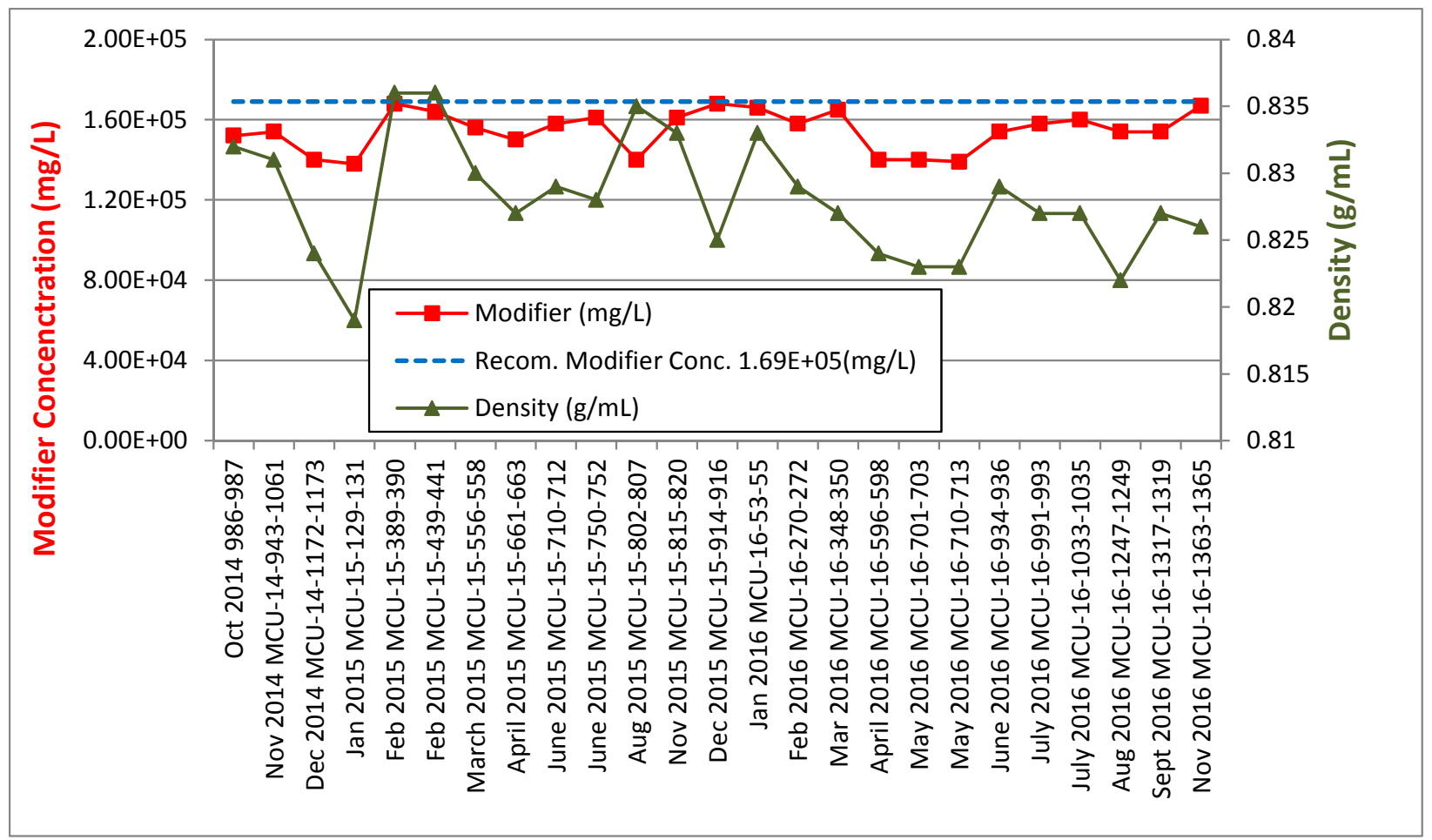

Figure 2. Modifier level in the solvent as measured by HPLC (one sigma is $\mathbf{1 0 \% )}$.

\section{Suppressors Levels}

The average TiDG concentration level $(1.34 \pm 0.3 \mathrm{E} 3 \mathrm{mg} / \mathrm{L})$ is at $93 \%$ of its nominal value of $1440 \mathrm{mg} / \mathrm{L}$ confirming the solvent trim addition on November 8, 2016 (a noticeable spike in the TiDG concentration level was observed in Fig. 3 in the November 2016 SHT monthly sample). The suppressor concentration is above its minimum recommended operating level $(479 \mathrm{mg} / \mathrm{L})$. The TOA concentration appears to remain steady and it is currently at $194 \pm 39 \mathrm{mg} / \mathrm{L}$. Since MCU no longer adds TOA, a drop in TOA concentration is expected with time. However, a detectable and steady TOA concentration persists with time, perhaps due to the degradation of TiDG into primary amines, which have previously been identified as degradation products of the suppressor when heated $\left(3{ }^{\circ} \mathrm{C}, 25{ }^{\circ} \mathrm{C}\right.$ and $\left.36{ }^{\circ} \mathrm{C}\right) .5$ The primary amine degradation products would likely have a similar pKa to the TOA (tertiary amine) making the equivalent points coincide. 6 


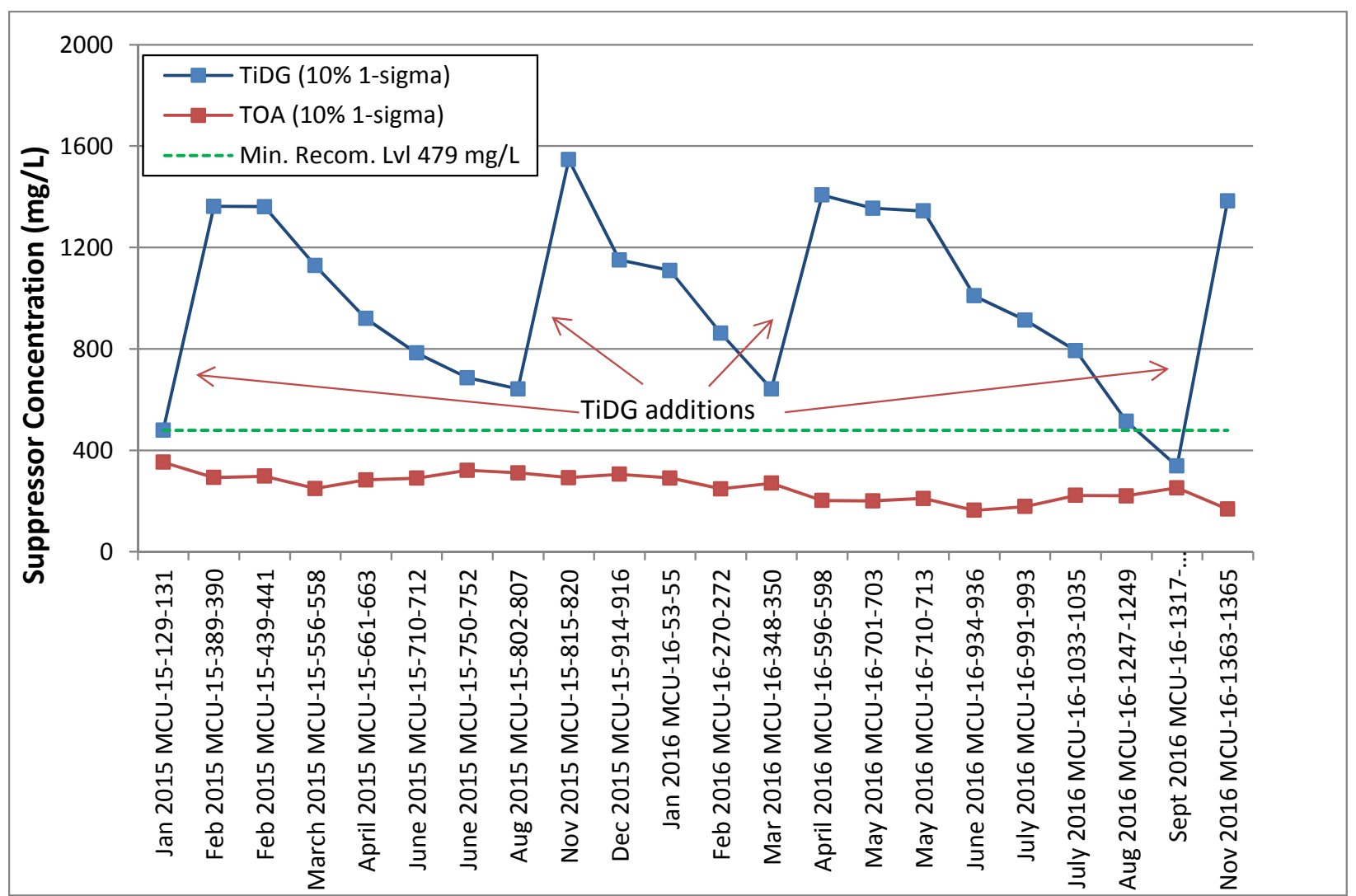

Figure 3. Suppressor concentration as measured by titration in SHT samples since NGS implementation. The minimum recommended level is $479 \mathrm{mg} / \mathrm{L}$ for TiDG.

\section{Extractant Levels}

The average calculated MaxCalix level is $4.23 \mathrm{E} 4 \mathrm{mg} / \mathrm{L}( \pm 10 \%)$ and it is at $8 \%$ below its nominal value. Note the current recommended value is the difference between $47,800 \mathrm{mg} / \mathrm{L}$ (50 mM MaxCalix) and the current BOBCalixC6 concentration in the SHT. The recent variation in the MaxCalix concentration seen in Fig. 4 is within the uncertainty range for this measurement. However, the current measurement appears to indicate a downward trend in the MaxCalix concentration possibly due to analytical, sampling or process variances since MaxCalix was added to MCU on November 8, 2016. The current "down and up" trend in the MaxCalix level has been previously observed after a solvent trim addition (see Fig. 4).

The residual concentration of BOBCalixC6 level is currently at 44\% of the level measured when the NGS was implemented in late FY13 (the concentration variability is due to analytical fluctuations). This level is approximately the same level observed in the July 2016 sample $(2.27 \mathrm{E} 3 \mathrm{mg} / \mathrm{L})$. Since no BOBCalixC6 is added to the SHT, the variable trend in BOBCalixC6 concentration with time is more reflective of the analytical uncertainty. Given that no BOBCalixC6 is added to the solvent, the level is expected to decrease with time. 


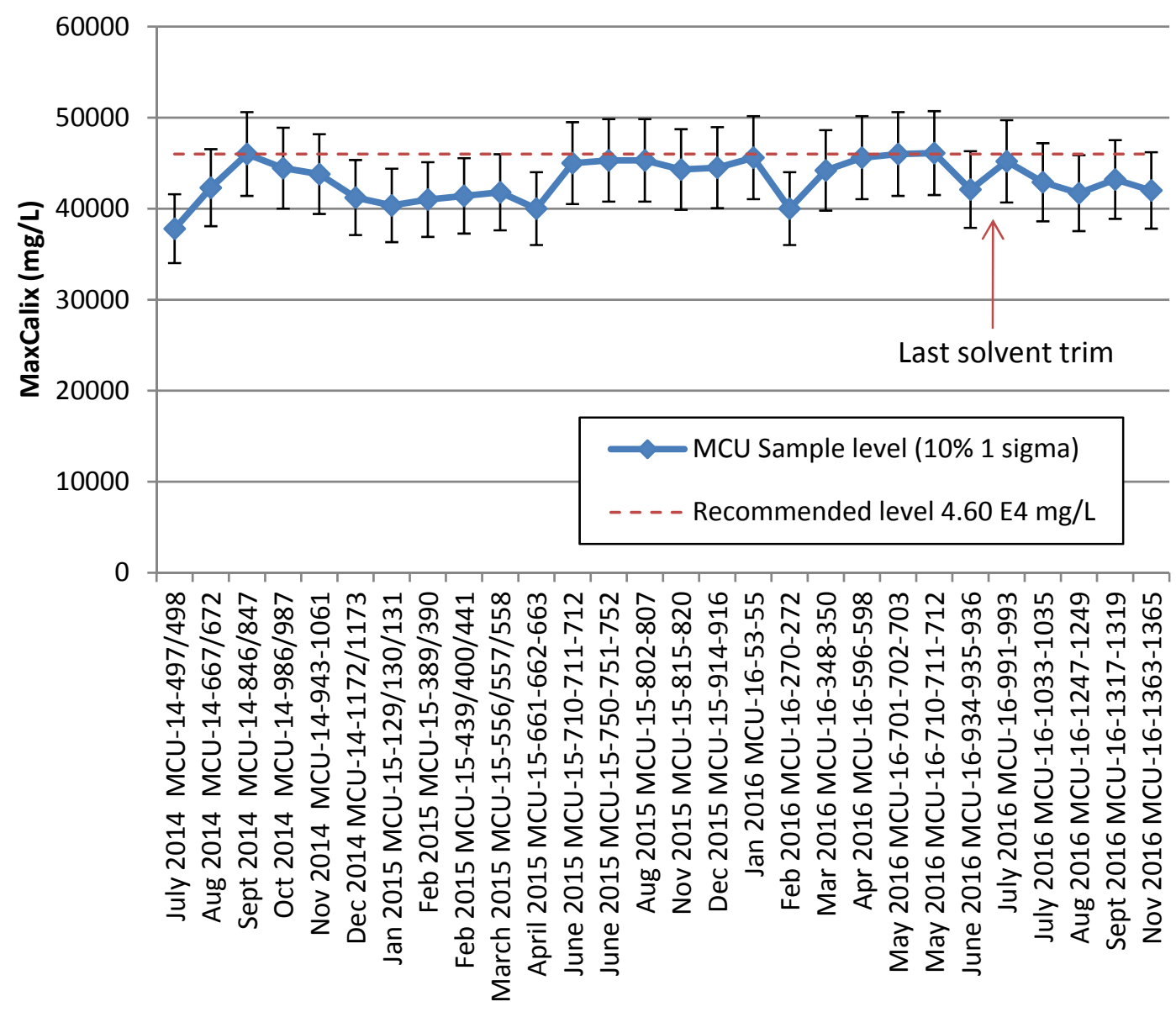

Figure 4. MaxCalix concentration as measured by HPLC and FT-HNMR of recent samples since NGS implementation $(46,000 \mathrm{mg} / \mathrm{L}$ is the nominal concentration).

\section{Gamma Level}

The gamma measurement of MCU-16-1363-1364-1365 is 1.76E5 dpm/mL ( $\pm 5 \%$ ) or approximately 1E6 $\mathrm{dpm} / \mathrm{g}$ modifier if the solvent is allowed to dry (for example, when the Isopar ${ }^{\mathrm{TM} L}$ is allowed to evaporate as in the case of solvent misting). This level of activity is consistent with the previous gamma levels when the process was operating normally in late 2015 and in early 2016 (the low Gamma count from the February 2016 sample is unclear at this point). It confirms the steady state trend level observed since March 2016 (see Fig. 5). 
SRNL-STI-2017-00101

Revision 0

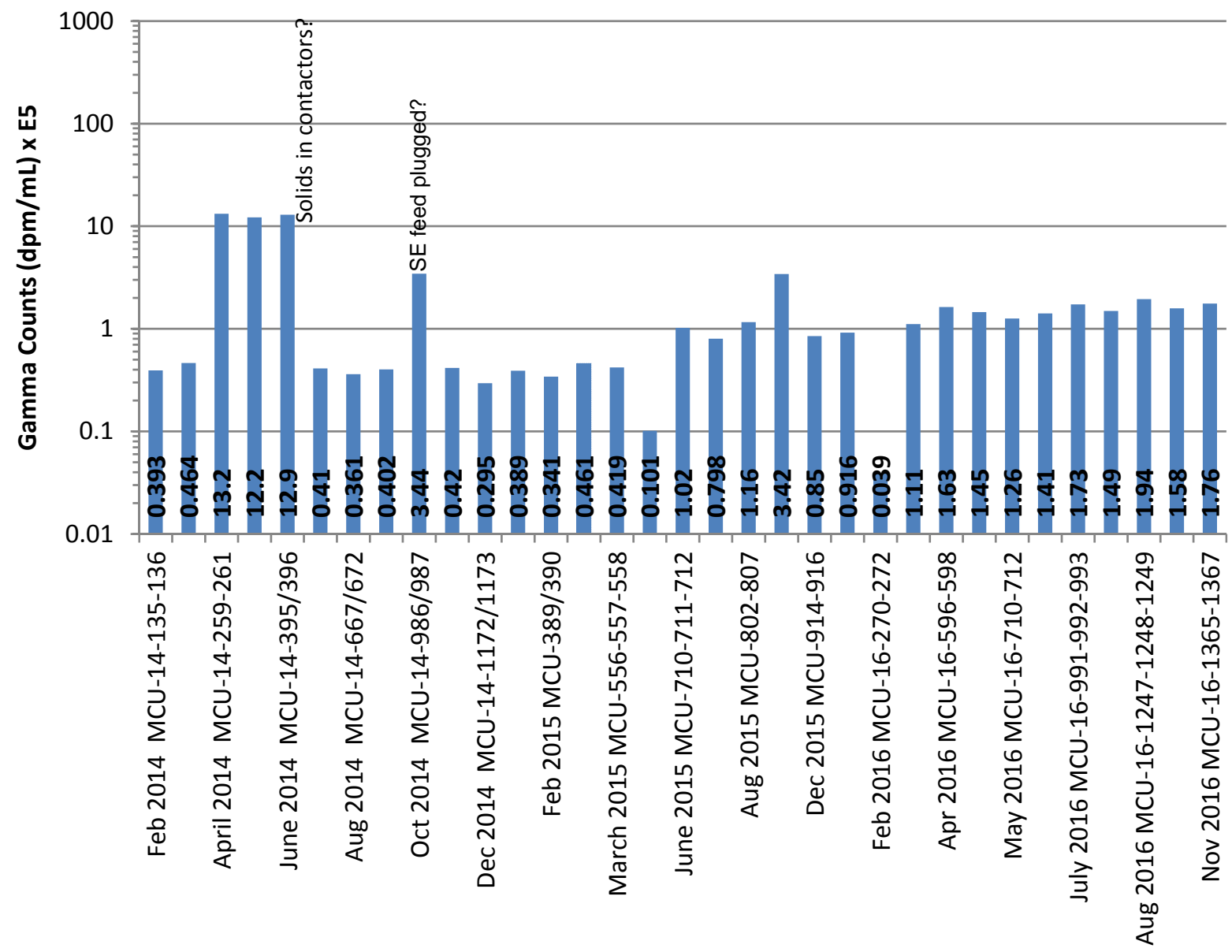

Figure 5. The gamma count of selected SHT samples. One sigma is $5 \%$.

\section{Impurities}

No impurities were seen at the $1000 \mathrm{ppm}$ level or higher as indicated by the SVOA method $( \pm 20 \%$ uncertainty). No impurities were observed in the HNMR spectrum.

A few milliliters of MCU-16-1363-1364-1365 was digested and analyzed for total mercury by the CVAA method. The CV-AA method detected a total mercury concentration of $26.0 \mathrm{ug} / \mathrm{g}_{\text {solvent }}$ of mercury. The XRF method also detected a concentration of $28.0 \mathrm{ug} / \mathrm{g}_{\text {solvent }}$ of mercury of the undigested MCU-16-13631364-1365 sample. The average of both methods is $27 \pm 5.4 \mathrm{ug} / \mathrm{g}_{\text {solvent }}$ of mercury (or $22.3 \mathrm{ug} / \mathrm{mL}_{\text {solvent }}$ at $\left.25^{\circ} \mathrm{C}\right)$.

This level of mercury is significantly higher than the solubility of metallic $\mathrm{Hg}$ in dodecane $(\sim 3 \mathrm{ppm}) 7$, implying that other solubility-enhancing mechanisms are at play (for example extraction by an extractant or sorption on trapped solids) or a more soluble form of mercury is present (organo-mercury like ethyl or dimethyl mercury). Organo-mercury compounds were recently detected in Tank 22H.8 For 200 gallons of solvent $(757.1 \mathrm{~L})$ and assuming a density of $0.826 \mathrm{~g} / \mathrm{mL}$, the solvent could contain a total of $16.9 \pm 3.4$ $\mathrm{g}$ of mercury (based on the average of the two measurements). A comparison of this measurement with previous months confirms a positive trend in the mercury concentration in the solvent (data is shown in Fig. 6). Please note all the XRF data since November were renormalized and compensated for solvent 
density variation in this report. Thus, these values differ (slightly lower values) from previous reports. The positive trend in Fig. 6 might be due to a higher mercury concentration in Salt Batches 8 and 9 (Tank $49 \mathrm{H})$. Also higher levels of total mercury $(\sim 109 \mathrm{ppm})$ were observed in Tank $50 \mathrm{H}$ third and fourth quarters surveillance samples. ${ }^{10}$

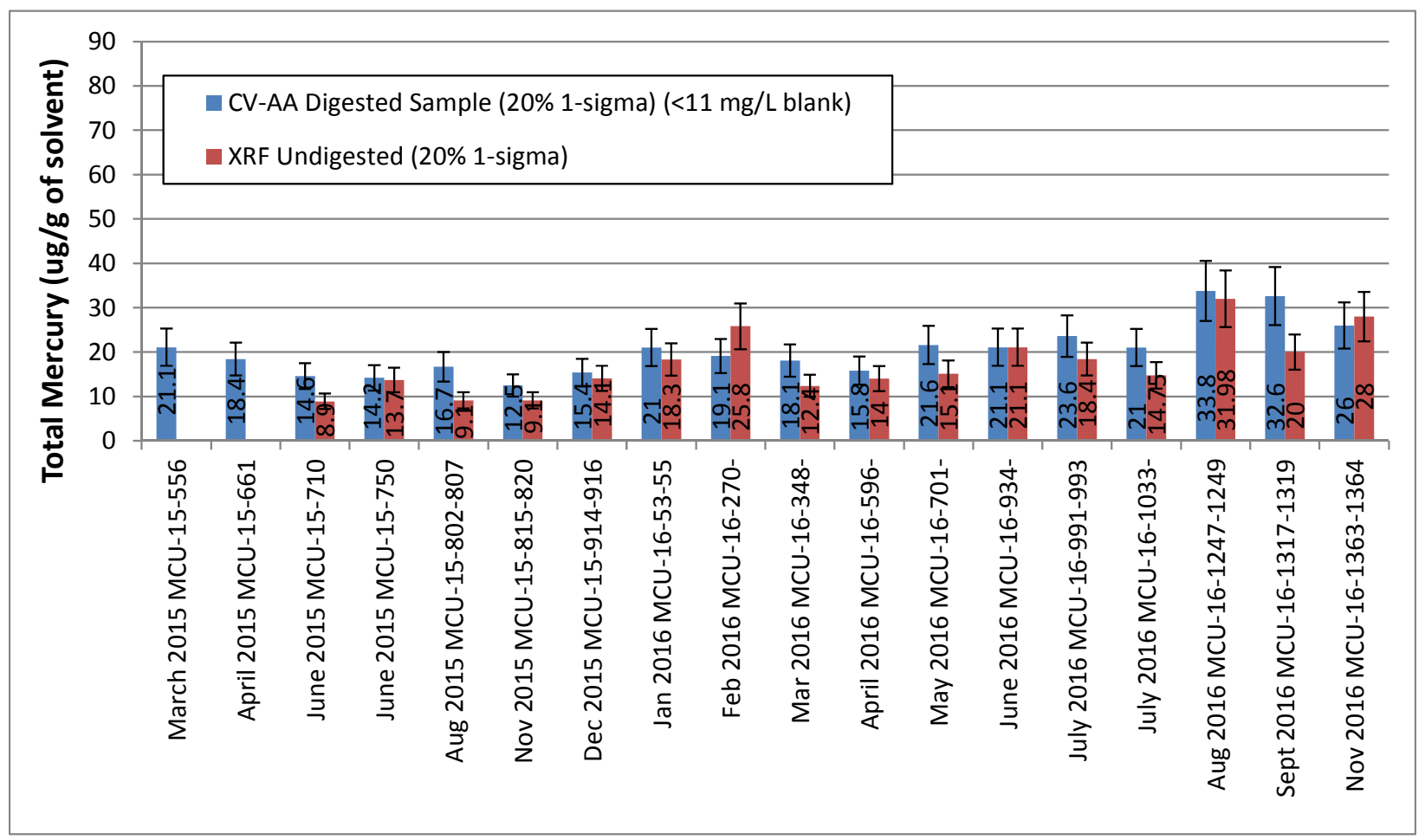

Figure 6. Total mercury in recent SHT samples. One sigma is $20 \%$. CVAA = Cold Vapor Atomic Absorption Spectrometry. XRF =X-ray Fluorescence (20\% one sigma).

\section{Recommendations}

The current analysis indicates the solvent has $92 \%$ of its nominal modifier and $93 \%$ of its suppressor (TiDG), but it has a nominal level of Isopar ${ }^{\mathrm{TM}} \mathrm{L}(100 \%)$ relative to the standard. The MaxCalix concentration is at $92 \%$ of its nominal level. The TiDG, MaxCalix, modifier, and Isopar ${ }^{\mathrm{TM}} \mathrm{L}$ amounts are expected to trend downward with time but at different rates. Based on the November sample, the solvent did not require any further trim addition.

The temperature dependence of the current gravimetric density equation for solvent composition (originally obtained from CSSX solvent) needs reverification with the current NGS-CSSX solvent to improve the formula accuracy in extracting the component concentrations in the solvent.

\subsection{Conclusions}

Savannah River National Laboratory (SRNL) received one set of three Solvent Hold Tank (SHT) samples (MCU-16-1363-1364-1365), pulled on 11/15/2016 for analysis. The samples were combined and analyzed for composition. Analysis of the composite sample MCU-16-1363-1364-1365 indicated the Isopar ${ }^{\mathrm{TM}} \mathrm{L}$ concentration is at its nominal level (100\%). The extractant (MaxCalix) and the modifier (CS$7 \mathrm{SB}$ ) are $8 \%$ and $2 \%$ below their nominal concentrations. The suppressor (TiDG) is $7 \%$ below its nominal concentration. 
This analysis confirms the Isopar ${ }^{\mathrm{TM}}$ addition to the solvent in November. This analysis also indicates the solvent did not required further additions. Based on the current monthly sample, the levels of TiDG, Isopar ${ }^{\mathrm{TM}} \mathrm{L}$, MaxCalix, and modifier are sufficient for continuing operation but are expected to decrease with time. Periodic characterization and trimming additions to the solvent are recommended. A solvent trim batch, containing TiDG, modifier and MaxCalix, was prepared by SRNL and was added to the SHT on December 14, 2016.

No impurities above the $1000 \mathrm{ppm}$ level were found in this solvent by the SVOA. No impurities were observed in the HNMR. However, there is evidence of possible chemical modification of the modifier with some missing a hydrogen atom at the tert-butyl group of the modifier. Another impurity observed in the samples was mercury. Up to $27 \pm 5.4$ micrograms of mercury per gram of solvent (or $22.3 \mu \mathrm{g} / \mathrm{mL}$ ) was detected in this sample (the average of the CV-AA and XRF methods).

The current gamma level $(1.76 \mathrm{E} 5 \mathrm{dpm} / \mathrm{mL})$ confirmed that the gamma concentration has returned to previous levels (as observed in the late 2015 samples) where the process operated normally and as expected.

The laboratory will continue to monitor the quality of the solvent in particular for any new impurities or degradation of the solvent components. 


\subsection{References}

1 W. M. Matthews, HLW-CRF-10006, Rev. 0, May 18, 2010.

2 M. R. Williams, “Next Generation Solvent Preparation” ITS-0173, July 11, 2013.

3 M. Santos, "Engineering Evaluation of MCU Solvent and Recommended Trim and Isopar ${ }^{\mathrm{TM} L}$ Addition to Maintain Specifications November 2016", X-ESR-H-00856, Rev. 0, November 10, 2016.

4 L. H. Delmau, J. F. Birdwell, Jr., P. V. Bonnesen, L. J. Foote, T. J. Haverlock, L. N. Klatt, D. D. Lee, R. A. Leonard, T. G. Levitskaia, M. P. Maskarinec, B. A. Moyer, F. V. Sloop, Jr., B. A. Tomkins, "CausticSide Solvent Extraction: Chemical and Physical Properties of the Optimized Solvent", ORNL/TM2002/190, October 2002.

${ }_{5}$ B. A Moyer, L. H. Delmau, B. D. Roach, and N. J. Williams, "Thermal Degradation of Next Generation Solvent using Triisodecylguanidine Suppressor: Impacts on Solvent Performance and Organic Content of Aqueous Effluents" ORNL-LTR-NGCSSX-020, Rev. 1, July 2013.

${ }_{6}$ K. M. L. Taylor-Pashow, F. F. Fondeur, T. L. White, D. P. Diprete, and C. E. Milliken, "Development of Analytical Methods for Determining Suppressor Concentration in the MCU Next Generation Solvent (NGS)"SRNL-STI-2013-00435, Rev. 0, July 2013.

7 H. L. Clever and M. Iwamoto, "Solubility of Mercury in Normal Alkanes", Ind. Eng. Chem. Res. (1987), 26, 336-337.

${ }_{8}$ C. J. Bannochie, "Result of Preliminary Hg Speciation Testing on Tank 22 and Waste Concentrate Hold Tank (WCHT) Material”, SRNL-L3100-2015-00079, Rev. 1, May 4, 2015.

${ }^{10}$ C. J. Bannochie, "Results of Hg Speciation Testing on 3Q16 and 4Q16 Tank 50 WAC samples", SRNL-L3100-2016-00222, Rev. 1, January 2017. 


\section{Distribution:}

A. P. Fellinger, 773-43A

T. B. Brown, 773-A

M. E. Cercy, 773-42A

D. A. Crowley, 773-43A

D. E. Dooley, 773-A

S. D. Fink, 773-A

C. C. Herman, 773-A

D. T. Hobbs, 773-A

E. N. Hoffman, 999-W

J. E. Hyatt, 773-A

K. M. Kostelnik, 773-42A

B. B. Looney, 773-42A

D. A. McGuire, 773-42A

T. O. Oliver, 773-42A

F. M. Pennebaker, 773-42A

G. N. Smoland, 773-42A

M. E. Stone, 999-W

A. L. Washington, 773-42A

W. R. Wilmarth, 773-A

B. J. Wiedenman, 773-42A

Records Administration (EDWS)

E. A. Brass, 241-121H

C. K. Chiu, 704-27S

J. S. Contardi, 704-56H

J. P. Schwenker, 704-56H

A. G. Garrison, 241-121H

V. X. Jain, 766-H

C. M. Santos, 241-152H

P. E. Fogelman, 241-121H

K. M. Marra, 241-120H

B. A. Gifford, 704-56H

R. T. McNew, 766-H

V. Jain, 766-H

P. R. Jackson, DOE-SR, 703-46A

J. A. Crenshaw, 703-46A

T. B. Peters, 773-42A

C. A. Nash, 773-42A

F. F. Fondeur, 773-A

K. M. L. Taylor-Pashow, 773-A

D. H. Jones, 999-W 